\title{
Swamedikasi diabetes mellitus dengan daun ceplikan (Ruellia tuberosa L.): kajian kemanfaatan pada profil lipid serum secara praklinik
}

\author{
Ety Yuni Ristanti' ${ }^{1}$ Wiryatun Lestariana ${ }^{2}$, Lily Arsanti Lestari ${ }^{3}$
}

\begin{abstract}
Background: Self-medication by using ceplikan leaves (Ruellia tuberosa L.) has been practiced in society for many times in the after-boiled form. It had been proved that liquid extract of ceplikan leaves (Ruellia tuberosa L.) was able to reduce blood glucose level on diabetic rat. It is also well known among diabetes mellitus patient that it has following effect on increasing triglyceride and reducing HDL-cholesterol level.

Objective: This research was aimed to give scientific evidence on the society habit on self-medication by using ceplikan leaves (Ruellia tuberosa L.) by examining its oral administration on serum lipid profile pre-clinically.

Method: Two months old Rattus novergicus within average weight of 150-200 g were divided into experimental and control groups. The control group consisted of 6 normal rats; while the experimental group consisted of 24 alloxan induced-diabetic rats. The experimental groups were divided into four groups i.e. non-treatment group and oral administrations of Ruellia tuberosa L. liquid extract with different concentrations that were $1.6 \mathrm{mg}, 3.2 \mathrm{mg}$, and $6.4 \mathrm{mg}$, respectively. The feeds were given ad libitum. The oral administrations of Ruellia tuberosa L. liquid extract were given everyday for 30 days. In the end of the treatment, all rats were fastened and the blood was taken from the eye and being observed for its serum lipid profile. The data were analyzed statistically by using ANOVA and Tukey's HSD mean difference tests. Results: The results showed that oral administration of $3.2 \mathrm{mg}$ Ruellia tuberosa L. liquid extract was significantly reduced triglyceride and LDL-cholesterol level $(p<0,05)$ and increased HDL-cholesterol level $(p<0,05)$.

Conclusion: The $3.2 \mathrm{mg}$ of Ruellia tuberosa L. liquid extract was able to reduce triglyceride and LDL-cholesterol level and increase HDL-cholesterol level. Moreover, ceplikan leaves (Ruellia tuberose L.) could be taken as traditional drugs in a non-formal way with control on dietary intake and regular physical exercise.
\end{abstract}

KEY WORDS self-medication, liquid extract of ceplikan leaves (Ruellia tuberosa L.), triglyceride, total cholesterol, LDLcholesterol, HDL-cholesterol, diabetes mellitus

\section{PENDAHULUAN}

Diabetes mellitus (DM) merupakan penyakit yang akan disandang seumur hidup oleh penderitanya, sehingga penatalaksanaannya memerlukan modifikasi cara hidup. Tujuan penatalaksanaan DM pada umumnya adalah memperbaiki kelainan metabolisme yang paling normal dengan harapan dapat mempertahankan status kesehatan penderita agar tetap baik (1). Dalam penatalaksanaan DM, langkah pertama yang harus dilakukan adalah perencanaan makan dan kegiatan jasmani. Jika dengan langkah tersebut sasaran pengendalian DM yang ditentukan belum tercapai, dapat dilanjutkan dengan penggunaan obat/pengelolaan farmakologis (2).

Penderita DM cenderung menderita komplikasi akut maupun kronik. Komplikasi kronik yang sering dijumpai adalah kelainan makrovasa berupa aterosklerosis yang didasari oleh kontrol diabetik yang tidak baik dan kelainan metabolisme lipid (1). Abnormalitas lipoprotein atau yang sering disebut dislipidemia yang biasa didapatkan pada penderita DM, seperti: peningkatan trigliserida, penurunan kadar kolesterol high density lipoprotein (HDL) dan low density lipoprotein (LDL) dikonversi dengan ukuran lebih kecil (3). Asdie (1) melaporkan bahwa di antara 55 kasus DM yang diteliti, hiperkolesterolemia dijumpai pada $21,83 \%$ pasien, hipertrigliseridemia pada $34,54 \%$ pasien, sedangkan kombinasi hiperkolesterolemia dan hipertrigliseridemia ditemukan pada $18,18 \%$ pasien. Dislipidemia mempunyai peran penting dalam manifestasi dan perkembangan dini aterosklerosis yang mengarah ke penyakit kardiovaskular.

Terapi oral ideal untuk DM adalah obat yang dapat mengontrol glukosa darah sekaligus mencegah perkembangan aterosklerosis dan komplikasi lain DM, namun pilihan obat yang tersedia sekarang ini masih terbatas (4). Oleh karena itu, dibutuhkan jalur penunjang untuk pengobatan konvensional pada penyakit DM dengan menggunakan sumber daya alam seperti bahan alam dari herbal yang memenuhi persyaratan pengobatan, yaitu : aman, berkhasiat, dan mudah dilaksanakan. Kontrol glukosa darah yang efektif dan aksi antioksidan merupakan kunci dalam mencegah DM

\footnotetext{
Politeknik Kesehatan Departemen Kesehatan R.I. Maluku Jurusan Gizi, Jl. Laksdya Wattimena Negeri Lama, Ambon, e-mai: ety_amq@yahoo.co.id

2 Bagian Biokima Fakultas Kedokteran UGM, JI Farmako, Sekip Utara, Yogyakarta 55281

3 Program Studi Gizi Kesehatan UGM, JI. Farmako Sekip Utara, Yogyakarta 55281, email: santi_wap@yahoo.com
} 
dan komplikasinya (5). Banyak tanaman herbal yang memiliki kedua efek tersebut, salah satunya adalah ceplikan (Ruellia tuberosa L). Pemanfaatan tanaman ceplikan sebagai tanaman obat merupakan kenyataan yang bersifat empirik yang telah dipraktikkan oleh masyarakat yang ada di wilayah Kabupaten Tojo Una-una, terutama dalam swamedikasi DM (6).

Berdasarkan penelitian pendahuluan yang telah dilakukan peneliti, ternyata di dalam ekstrak air daun ceplikan mengandung senyawa aktif saponin, flavonoid, juga mengandung mineral seng $(35,5 \mathrm{ppm})$ dan serat $(13,55 \%)$ yang mempunyai manfaat sebagai antioksidan, menurunkan kadar glukosa darah, dan membantu menurunkan kadar kolesterol $(7,8)$.

Dalam penelitian ini dilakukan pembuatan sediaan ekstrak air karena masyarakat biasanya menggunakan air rebusan daun ceplikan sehingga diharapkan dengan ekstrak air, senyawa-senyawa yang larut dalam rebusan juga ikut serta dalam ekstrak air, dan juga akan memudahkan pengaturan konsentrasi zat berkhasiat tersebut (9).

Tandri (6) telah melakukan penelitian efek hipoglikemik dari ekstrak air daun ceplikan dan diperoleh hasil penurunan kadar glukosa darah tikus Rattus norvegicus. Pada penderita DM, biasanya terjadi kenaikan kadar kolesterol total, trigliserida, dan kolesterol LDL, sehingga perlu dilakukan penelitian kebenaran bahwa ceplikan juga dapat mempengaruhi kadar profil lipid.

Tujuan penelitian ini adalah untuk memberi landasan ilmiah bagi kebiasaan swamedikasi DM oleh masyarakat dengan daun ceplikan melalui pengkajian efek daun ceplikan terhadap profil lipid serum secara praklinis pada tikus putih jantan galur wistar (Rattus norvegicus).

\section{BAHAN DAN METODE}

Penelitian ini merupakan penelitian eksperimental murni dengan rancangan pre-post test control group design. Bahan yang digunakan meliputi: daun ceplikan, akuades, aloksan, $\mathrm{NaCl} 10 \%$, reagen trigliserida, dan reagen kolesterol FS. Alat yang digunakan adalah spektrofotometer, kandang individual, timbangan berat badan tikus, timbangan analitik, tabung reaksi, jarum peroral, sentrifuse, scalpel blade, mikropipet, ependorf, dan vortek.

Subjek penelitian adalah tikus Rattus norvegicus berumur 2-3 bulan dengan berat badan rata-rata antara 150-200 g sebanyak 30 ekor yang diperoleh dari Layanan Penelitian Praklinik dan Pengembangan Hewan Percobaan (LP3HP) UGM.

Penelitian ini dilaksanakan di Laboratorium Penelitian dan Pengujian Terpadu (LPPT) Unit I UGM sebagai tempat analisis senyawa aktif ekstrak air daun ceplikan, pemeriksaan glukosa darah, dan profil lipid. LP3HP UGM digunakan sebagai tempat pemeliharaan hewan percobaan.

Tahap penelitian meliputi: identifikasi tanaman ceplikan, pembuatan ekstrak air daun ceplikan penelitian, pembuatan ekstrak air daun ceplikan dengan metode maserasi dan pemeriksaan senyawa bioaktif. Penelitian efek ekstrak air daun ceplikan pada tikus Rattus norvegicus jantan dilakukan dengan membuat tikus DM dengan induksi aloksan dosis $170 \mathrm{mg} / \mathrm{kg}$ BB, mengelompokkan hewan percobaan menjadi 5 kelompok, yaitu kelompok kontrol normal diberi akuades, kontrol DM diberi akuades, DM diberi ekstrak air daun ceplikan dosis $1,6 \mathrm{mg} / 0,5 \mathrm{~mL}$, dosis $3,2 \mathrm{mg} / 0,5 \mathrm{~mL}$, dan dosis 6,4 $\mathrm{mg} / 0,5 \mathrm{~mL}$. Perlakuan dilakukan selama 30 hari secara oral.

Pemeriksaan profil lipid dilakukan sebelum dan sesudah perlakuan. Pemeriksaan kadar trigliserida dengan metode GPO (glycerol 3 phosphate oxidase), kadar kolesterol total, LDL dan HDL dengan metode CHOD-PAP.

Hasil dinyatakan dalam bentuk mean \pm SD. Analisis statistik dilakukan dengan one-wayANOVA dilanjutkan dengan uji beda mean Tukey'S HSD dan t-test.

\section{HASIL DAN BAHASAN}

DM yang tidak dikelola dengan baik dapat mengakibatkan terjadinya berbagai penyulit menahun. Dalam mengelola DM, langkah pertama yang harus dilakukan adalah perencanaan diet dan kegiatan jasmani (2). Dengan diet yang benar, maka toleransi glukosa dapat menjadi normal. Diet bagi pengidap DM adalah diet dengan kalori berimbang yang memperhatikan pedoman 3J (jumlah, jenis, dan jadwal makan) (1). Kegiatan jasmani sehari-hari dan latihan jasmani secara teratur (3-4 kali seminggu selama kurang lebih 30 menit) juga merupakan salah satu pilar dalam pengelolaan DM tipe 2. Latihan jasmani dapat menjaga kebugaran, menurunkan berat badan, dan memperbaiki sensitivitas insulin, sehingga memperbaiki kendali glukosa darah (10). Selain itu, olahraga yang teratur menunjukkan efek terhadap metabolisme lipid. Kadar trigliserida plasma menurun dengan berolahraga, sedangkan HDL-kolesterol meningkat.

Apabila pengelolaan nonfarmakologis belum tercapai, dilanjutkan dengan pengunaan obat/pengelolaan farmakologis dengan obat hipoglikemik oral (OHO) dan atau dengan suntikan insulin (2). Penemuan obat DM yang murah dan efektif menurunkan kadar glukosa darah sangat dibutuhkan, karena DM merupakan penyakit yang memerlukan pengobatan seumur hidup, sehingga perlu dicari alternatif obat-obat tradisional $(11,12)$.

Swamedikasi DM dengan daun ceplikan sudah lama dilakukan oleh masyarakat Tojo Una-una (6). Berdasarkan hasil wawancara diketahui bahwa masyarakat menggunakan daun ceplikan sebagai obat DM dalam bentuk rebusan, yaitu dengan merebus 7 lembar daun ceplikan dengan 2 gelas air, sehingga menghasilkan 1 gelas air rebusan yang diminum sebelum makan sebanyak 2-3 kali sehari dan penderita DM tidak perlu melakukan diet. Setelah minum rebusan daun ceplikan selama 3 hari, keluhan-keluhan yang biasa dirasakan oleh penderita DM menjadi berkurang.

Pada penelitian praklinis ini, digunakan tikus DM induksi aloksan dengan kadar glukosa darah $\geq 250 \mathrm{mg} / \mathrm{dL}$. Rata-rata 
berat badan semua tikus sama pada awal perlakuan. Bertambahnya umur tikus menyebabkan tikus kontrol normal mengalami penambahan berat badan yang signifikan $(p=0,000)$, sedangkan pada kelompok lain terjadi penurunan berat badan sampai akhir penelitian. Kelompok tikus DM tanpa perlakuan mengalami penurunan berat badan yang tidak signifikan $(p=$ $0,456)$. Kelompok tikus DM dengan perlakuan ekstrak air daun ceplikan dosis $1(1,6 \mathrm{mg})$ dan dosis $2(3,2 \mathrm{mg})$ mengalami penurunan berat badan yang signifikan. Penurunan berat badan tersebut sejalan dengan berat pakan yang dikonsumsi. Hal ini dapat dilihat dari hasil penimbangan berat pakan yang menurun pada akhir penelitian yang berakibat penurunan berat badan tikus.

Penurunan berat badan ini dapat terjadi karena adanya penurunan insulin yang memicu hilangnya jaringan adiposa serta perubahan dalam metabolisme karbohidrat dan protein yang terjadi pada tikus DM (13). Hasil penelitian yang dilakukan oleh Trivedi et al.(4) menunjukkan bahwa penurunan berat badan yang stabil teramati pada tikus diabetik yang diinduksi dengan aloksan dan penurunan tersebut menjadi bermakna setelah 2 minggu sejak pemberian aloksan. Shilajit (obat DM tradisional yang digunakan oleh suku Aryaveda di India) tidak berpengaruh terhadap berat badan, namun penurunan berat badan yang bermakna ditemukan pada tikus diabetik yang diinduksi aloksan.

Tabel 1 menunjukkan efek dari pemberian oral ekstrak air daun ceplikan terhadap kadar profil lipid serum. Tikus kontrol DM menunjukkan peningkatan kadar kolesterol total, trigliserida, kolesterol LDL, dan penurunan kolesterol HDL dibandingkan kontrol normal. Setelah diberi ekstrak air daun ceplikan, tikus kontrol DM tersebut menunjukkan adanya penurunan kadar kolesterol total, trigliserida, dan kolesterol LDL serta peningkatan kolesterol HDL. Pemberian ekstrak air daun ceplikan dosis 2 (3,2 $\mathrm{mg})$ menurunkan kadar trigliserida secara bermakna $(p=0,002)$ dan juga menurunkan kadar kolesterol LDL secara bermakna $(p=0,001)$. Pemberian ekstrak air daun ceplikan dosis 3 (6,4 mg) dapat menurunkan kadar trigliserida dan kolesterol LDL secara bermakna. Hasil analisis ANOVA menunjukkan perbedaan yang bermakna ratarata perubahan kadar trigliserida, kolesterol LDL, dan kolesterol HDL antara kelompok DM tanpa perlakuan dengan kelompok DM yang diberi ekstrak air daun ceplikan dosis 2 $(3,2 \mathrm{mg})(\mathrm{p}<0,05)$. Penurunan maksimum kadar kolesterol total, trigliserida dan kolesterol LDL dicapai oleh ekstrak air daun ceplikan dosis 2 ( $3,2 \mathrm{mg}$ ). Peningkatan maksimal kadar kolesterol HDL juga dicapai oleh ekstrak air daun ceplikan dosis 2 (3,2 mg).

Tandri (6) meneliti efek hipoglikemik dari ekstrak air daun ceplikan pada tikus DM induksi aloksan. Induksi aloksan menghasilkan hampir 5 kali lipat peningkatan kadar glukosa darah pada tikus putih. Tikus DM dengan perlakuan ekstrak air daun ceplikan dosis 1 (1,6 mg), dosis 2 (3,2 mg), dan dosis $3(6,4 \mathrm{mg})$ menunjukkan pengurangan yang lebih besar kadar glukosa darah dibandingkan dengan tikus DM tanpa perlakuan. Penurunan maksimal kadar glukosa darah dicapai oleh ekstrak air daun ceplikan dosis 1,6 mg.

Setelah diberi aloksan, tikus dapat mengalami suatu kondisi hiperkolesterolemia dan hipertrigliserida dengan

TABEL 1. Kadar profil lipid serum pada kontrol normal, kontrol diabetes, dan ekstrak air daun ceplikan (Ruellia tuberosa L.)

\begin{tabular}{|c|c|c|c|c|c|}
\hline \multirow[b]{2}{*}{ Parameter } & \multirow{2}{*}{$\frac{\text { Kontrol }}{\text { normal }}$} & \multicolumn{4}{|c|}{ Perlakuan } \\
\hline & & Diabetes & $\begin{array}{c}\text { Diabetes + } \\
\text { EADC } 1 \\
\end{array}$ & $\begin{array}{c}\text { Diabetes + } \\
\text { EADC } 2 \\
\end{array}$ & $\begin{array}{c}\text { Diabetes + } \\
\text { EADC } 3 \\
\end{array}$ \\
\hline \multicolumn{6}{|l|}{ Kolesterol total } \\
\hline Awal & $60,30 \pm 11,27$ & $102,22 \pm 18,98$ & $100,78 \pm 28,38$ & $96,38 \pm 17,04$ & $98,87 \pm 20,58$ \\
\hline Akhir & $60,45 \pm 7,11$ & $111,68 \pm 22,22$ & $98,08 \pm 11,03$ & $76,68 \pm 14,73$ & $90,92 \pm 16,66$ \\
\hline Perubahan* & $0,15 \pm 8,61^{\mathrm{a}}$ & $9,47 \pm 16,82^{\mathrm{a}}$ & $-2,70 \pm 22,03^{\mathrm{a}}$ & $-19,70 \pm 19,35^{a}$ & $-7,95 \pm 27,05^{a}$ \\
\hline $\mathrm{p}$ & 0,968 & 0,226 & 0,776 & 0,050 & 0,504 \\
\hline \multicolumn{6}{|l|}{ Trigliserida } \\
\hline Awal & $56,37 \pm 5,12$ & $82,83 \pm 26,53$ & $85,98 \pm 17,87$ & $84,12 \pm 18,30$ & $86,80 \pm 14,25$ \\
\hline Akhir & $56,12 \pm 8,14$ & $95,55 \pm 26,88$ & $74,90 \pm 29,32$ & $58,62 \pm 10,90$ & $77,60 \pm 20,09$ \\
\hline Perubahan* & $-0,25 \pm 6,44^{a}$ & $12,72 \pm 16,09^{a}$ & $-11,08 \pm 29,63^{a}$ & $-25,50 \pm 10,14^{b}$ & $-9,20 \pm 6,96^{\mathrm{a}}$ \\
\hline $\mathrm{p}$ & 0,928 & 0,111 & 0,402 & $0,002^{* *}$ & $0,023^{* *}$ \\
\hline \multicolumn{6}{|l|}{ Kolesterol LDL } \\
\hline Awal & $24,35 \pm 2,72$ & $50,02 \pm 19,41$ & $48,48 \pm 10,56$ & $47,93 \pm 10,65$ & $50,87 \pm 6,14$ \\
\hline Akhir & $28,31 \pm 3,75$ & $58,73 \pm 21,80$ & $39,27 \pm 7,56$ & $30,75 \pm 6,12$ & $36,23 \pm 3,35$ \\
\hline Perubahan* & $3,97 \pm 4,31^{a}$ & $8,72 \pm 26,03^{a}$ & $-9,22 \pm 15,63^{a}$ & $-17,18 \pm 5,85^{b}$ & $-14,63 \pm 5,09^{a}$ \\
\hline $\mathrm{p}$ & 0,074 & 0,449 & 0,208 & $0,001^{* *}$ & $0,001^{\star *}$ \\
\hline \multicolumn{6}{|l|}{ Kolesterol HDL } \\
\hline Awal & $39,32 \pm 5,73$ & $39,30 \pm 8,43$ & $39,43 \pm 4,90$ & $37,30 \pm 6,37$ & $37,15 \pm 14,64$ \\
\hline Akhir & $40,53 \pm 3,40$ & $27,82 \pm 8,29$ & $40,68 \pm 8,23$ & $40,95 \pm 11,22$ & $39,42 \pm 10,41$ \\
\hline Perubahan* & $1,22 \pm 10,04^{\mathrm{a}}$ & $-11,48 \pm 6,86^{a}$ & $1,25 \pm 9,10^{a}$ & $3,65 \pm 9,40^{b}$ & $2,27 \pm 5,44^{\mathrm{a}}$ \\
\hline $\mathrm{p}$ & 0,779 & 0,009 & 0,750 & 0,385 & 0,354 \\
\hline
\end{tabular}


peningkatan kadar kolesterol LDL. Abnormalitas metabolisme lipid pada DM secara umum akan menyebabkan peningkatan lipoprotein dan lipid serum yang pada akhirnya berperan penting dalam terbentuknya aterosklerosis yang berat dan prematur. Defisiensi insulin pada DM menginduksi sintesis lipase yang akan meningkatkan lipolisis dan mempertinggi konsentrasi asam lemak bebas di plasma dan hepar. Kadar glukagon juga meningkat pada DM, sehingga meningkatkan pelepasan asam lemak. Asam lemak yang berlebihan di dalam serum akan mendorong konversinya menjadi kolesterol dan trigliserida bersamaan dengan peningkatan kolesterol LDL. Pada saat yang bersamaan, defisiensi insulin juga meningkatkan kadar kolesterol LDL dan dengan demikian juga meningkatkan kadar kolesterol (5).

Terapi pada tikus DM dengan ekstrak air daun ceplikan dapat menurunkan kadar trigliserida dan kolesterol LDL juga meningkatkan kadar kolesterol HDL secara signifikan, yaitu pada tikus yang diberi ekstrak air daun ceplikan dosis 2 (3,2 $\mathrm{mg})$ jika dibandingkan tikus kontrol DM $(p<0,05)$. Namun demikian, penurunan kadar kolesterol total tidak signifikan ( $p$ $>0,05$ ). Kontrol glikemik dengan herba antidiabetik berhubungan dengan efek hipokolesterolemia dan normolipidemik terhadap hiperlipidemia pada tikus diabetik yang diinduksi dengan aloksan (5). Hal ini sesuai dengan hasil penelitian Li Xue et al.(14) yang melaporkan bahwa pemberian Trigonella foenumgraecum di samping menurunkan kadar trigliserida dan kolesterol total, juga meningkatkan kadar kolesterol HDL secara signifikan tergantung dosis $(p<0,01)$. Pemberian Trigonella foenum-graecum pada tikus DM bisa mengurangi kadar kolesterol total dan trigliserida dengan menurunkan asam lemak nonteresterifikasi (non-esterified fatty acid-NEFA) pada tikus DM. NEFA dapat mempengaruhi agregasi platelet dan perubahan pembuluh darah dengan meningkatkan jumlah prostasiklin dalam plasma. Penelitian lain pemberian ekstrak Nerium oleander pada tikus diabetik menawarkan perlindungan dalam profil lipid (13).

Aksi hipolipidemik dapat menimbulkan penurunan karbohidrat dan absorpsi lemak karena adanya serat dalam ekstrak air daun ceplikan. Pemberian serat dalam makanan berpengaruh pada penurunan kadar glukosa dan lemak darah. Ada dugaan bahwa makanan yang mengandung serat tinggi meningkatkan sensitivitas jaringan terhadap insulin (1). Dalam hal ini, fungsi serat yaitu mencegah adanya penyerapan kembali asam empedu, kolesterol, dan lemak sehingga serat dikatakan mempunyai efek hipolipidemik (15). Mekanisme lain yang mungkin tergantung pada besarnya kandungan senyawa bioaktif dalam ekstrak air daun ceplikan, yaitu sa- ponin dan flavonoid (7). Saponin juga dilaporkan memiliki efek hipolipidemik, misalnya: mengurangi kadar kolesterol, trigliserida, dan kolesterol LDL pada tikus hiperlipidemik (8). Saponin juga meningkatkan aktivitas reseptor LDL di hepar dan mengurangi sintesis trigliserida (5).

Flavonoid sebagai senyawa pereduksi dapat menghambat reaksi oksidasi karena memiliki aktivitas sebagai antioksidan. Antioksidan ini dapat menetralisir senyawa-senyawa radikal bebas. Aktivitas antioksidan dari flavonoid dapat menurunkan kadar kolesterol dengan cara menghambat oksidasi kolesterol LDL $(16,17)$.

Ekstrak air daun ceplikan juga mengandung zink sebesar $35,5 \mathrm{ppm}$. Zink memegang peranan esensial dalam banyak fungsi tubuh. Sebagai bagian dari enzim atau sebagai kofaktor pada kegiatan lebih dari dua ratus enzim, zink berperan dalam berbagai aspek metabolisme, seperti reaksi-reaksi yang berkaitan dengan sintesis dan degradasi karbohidrat, protein, lipid, dan asam nukleat (18).

Berdasarkan uji praklinik, daun ceplikan terbukti berkhasiat dalam menurunkan kadar glukosa darah, kadar trigliserida, dan kolesterol LDL, serta meningkatkan kadar HDL-kolesterol sehingga daun ceplikan bisa digunakan oleh masyarakat sebagai obat tradisional DM pada jalur nonformal dengan tetap memperhatikan pengaturan makan atau diet dan latihan jasmani secara teratur. Menurut Li Xue et al.(14), di antara berbagai bentuk terapi untuk DM, makanan merupakan salah satu terapi yang pokok. Makanan disertai dengan pendekatan medis terbukti efektif, sehingga dapat digunakan secara luas sebagai kesatuan dari dua faktor dasar yang penting yaitu makanan dan medikasi.

\section{KESIMPULAN DAN SARAN}

Berdasarkan hasil penelitian, dapat disimpulkan bahwa pemberian ekstrak air daun ceplikan dosis $3,2 \mathrm{mg}$ selama 30 hari pada tikus Rattus norvegicus DM dapat menurunkan kadar kolesterol total secara tidak signifikan, menurunkan kadar trigliserida dan kolesterol LDL secara signifikan $(p<$ $0,05)$, serta meningkatkan kadar HDL-kolesterol secara signifikan $(p<0,05)$.

Berdasarkan hasil penelitian tersebut, disarankan agar pengobatan DM dengan daun ceplikan bisa diterapkan di masyarakat dengan tetap memperhatikan pengaturan diet dan latihan jasmani secara teratur. Perlu pula dilakukan uji klinik pada orang sehat dan atau orang sakit agar daun ceplikan sebagai obat DM dapat dimasukkan ke dalam pelayanan kesehatan. 


\section{RUJUKAN}

1. Asdie AH. Patogenesis dan Terapi Diabetes Mellitus Tipe 2. Yogyakarta: Medika FK UGM; 2000.

2. Waspadji S. Diabetes Mellitus: Mekanisme Dasar dan Pengelolaan yang Rasional dalam Penatalaksanaan Diabetes Mellitus Terpadu. Jakarta: Pusat Diabetes dan Lipid RSUP Nasional RSCM dan FKUI; 2005. p. 21-32.

3. Goldberg JI. Diabetic Dyslipidemia: Causes and Consequences. J Clin Endocrinol Metab 2001;86(3):956-71.

4. Trivedi NA, Mazumdar B, Bhatt JD, Hemavathi KG. Effect of Shilajit on Blood Glucose and Lipid profile in AlloxanInduced Diabetic Rats. Indian J Pharmacol 2004;36(6):373-6.

5. Hussein HM, El-Sayed EM, Said AA. Antihyperglycemic, Antihiperlipidemic and Antioxidant Effect of Zizyphus spina christi and Zizyphus jujuba in Alloxan Diabetic Rats. Int J Pharmacol 2006;2(5):563-70.

6. Tandri TH. Pengaruh Pemberian Ekstrak Air Daun Ceplikan (Ruellia tuberosa L.) terhadap Kadar Glukosa Darah dan Gambaran Histologis Sel Beta Pankreas pada Tikus Putih (Rattus norvegicus) Diabetes Melitus [tesis]. Yogyakarta: Universitas Gadjah Mada; 2008.

7. Fwu Lin C, Ling Huang Y, Ying Cheng L, Jyi Sheu S, Chih Chen C. Bioactive Flavonoid from Ruellia tuberosa L. J Chin Med 2006;17(3):103-9.

8. Li M, Qu W, Wang Y, Wan H, Tian C. Hypoglycemic Effect of Saponin from Tribulus terrestris. Zhong Yao Cai 2002;25(6):420-2.

9. Anief M. IImu Meracik Obat Teori dan Praktik. Yogyakarta: Gadjah Mada University Press; 1999.
10. Perkeni. Konsensus Pengelolaan Diabetes Melitus Tipe 2 Di Indonesia. Jakarta: PB Perkeni; 2006.

11. Suyono S. Patofisiologi Diabetes Mellitus. In: Soegondo S, Soewondo P, Subekti I, editors. Penatalaksanaan Diabetes Mellitus Terpadu. Jakarta: Pusat Diabetes dan Lipid RSUP Nasional RSCM dan FKUI Bekerja Sama dengan Departemen Kesehatan RI dan WHO; 2005. p. 5-10.

12. Sreemantula S, Kilari EK, Vardhan VA, Jaladi R. Influence of Antioxidant (L-ascorbic acid) on Tolbutamide Induced Hypoglycaemia/Antihyperglycaemia in Normal and Diabetic Rats. BMC Endocr Disord 2005; 5(2): 1-5.

13. Yassin MM, Mwafy SN. Protective Potential of Glimepirid and Nerium Oelander Exctract on Lipid Profile, Body Growth Rate, and Renal Function in Streptozotocin Induced Diabetic Rats. Turk J Biol 2007;31:95-102.

14. Li Xue W, She Li X, Zhang J, Hui Liu Y, Lun Wang Z, Juan Zhang R. Effect of Trigonella foenum-graecum (fenugreek) Extract on Blood Glucose, Blood Lipid and Hemorheological Properties in Streptozotocin-Induced Diabetic Rats. Asia Pac J Clin Nutr 2007;16(Suppl I): 422-6.

15. Budiyanto MAK. Dasar-Dasar IImu Gizi. Malang: Universitas Muhammadiyah Malang; 2004.

16. Miller A L. Antioxidant Flavonoid: Structure, Function and Clinical Usage. Altern Med Rev 1996;1(2):103-11.

17. Winarsi $H$. Isoflavon sebagai Sumber, Sifat dan Manfaatnya Pada Penyakit Degeneratif. Yogyakarta: Gadjah Mada University Press; 2005.

18. Almatsier S. Prinsip Dasar Gizi. Jakarta: PT Gramedia Pustaka Utama; 2003. 